https://doi.org/10.31470/2706-7904-2021-16-200-204

\title{
РОЗВИТОК РЕФЛЕКСИВНИХ МОВЛЕННСВИХ ПРОЦЕСІВ У ДОШКІЛЬНИКІВ
}

Development of Reflective Speech Processes in Preschoolers

\author{
Iryna Lutsenko \\ Dr. Sc. in Pedagogical, Professor \\ Institute of Education Problems of the National Academy of \\ Pedagogical Sciences of Ukraine \\ sofiras@ukr.net \\ https://orcid.org/0000-0001-8360-9943
}

\begin{abstract}
The article analyzes domestic and foreign psycholinguistic research on the manifestations of reflection on language and speech in preschoolers in situations of natural speech communication. The most characteristic manifestations of linguistic reflection are highlighted, namely: correction of speech of interlocutors (children and adults), linguistic assessments of one's own speech and the speech of others, cases of children's etymology, metalanguage issues, meaning of words. Such manifestations of speech reflection as: judgments about the elements of speech, making adjustments to their speech in the process of expression, simplification of lexical and grammatical means in communication with younger children.

It is concluded that reflection occurs in children as a necessary component of the natural process of language acquisition and speech development. Manifestations of reflection in preschoolers in situations of natural communication contribute to the control and regulation of their speech, but by their nature they are spontaneous and situational.
\end{abstract}

Key words: speech reflection, arbitrariness, intentionality, awareness.

\section{Вступ \\ Introduction}

Проблема мовленнєвої рефлексії $є$ предметом уваги психолінгвістики, зокрема рефлексивної. Однак, на погляд О. Леонтьєва, теорія рефлексії мовця над мовленням відсутня. I це, не зважаючи на важливість їі практичного аспекту, а саме: управління мовленнєвими процесами на основі рефлексії. Уявлення про процеси усвідомлення дитиною мови, якою вона практично користується розвинулись нині до виділення характеристик, які засвідчують перехід від автоматичного використання мовленнєвих умінь, тобто спонтанних мовленнєвих процесів до усвідомлених - рефлексивних. 
У зв’язку з психологічним змістом навчання рідної мови, Л. Виготський ввів у науковий обіг такі характеристики усвідомлення мовленнєвих процесів, як: довільність, навмисність, усвідомленість. Вчений вважав, що рефлексія формується в молодшому шкільному віці шляхом засвоєння наукових знань (Выготский, 1984).

Витоками сучасного розуміння розвитку рефлексивного ставлення дитини до мови i мовлення є праці Л. Божович, Л. Виготського, Д. Ельконіна, О. Леонтьєва, Г. Цукерман. Так, Г. Цукерман послуговується поняттям визначальної рефлексії, формула якої: я знаю, i я знаю, що знаю (або не знаю) це (Цукерман, 1989). Отже, на етапі становлення рефлексивної психолінгвістики рефлексивна діяльність дитини над мовою теоретично обгрунтовувалась і досліджувалась в ситуації організованого навчання.

Мета дослідження полягає у вивченні й аналізі праць, присвячених проявам рефлексивних мовленнєвих процесів у дітей дошкільного віку в ситуаціях природного мовленнєвого спілкування.

\section{Методи та методики дослідження Methods and Techniques of the Research}

У процесі вивчення особливостей розвитку спонтанних i рефлексивних мовленнєвих процесів у дітей дошкільного віку використовувались такі теоретичні методи: (1) аналіз вітчизняних i зарубіжних психолінгвістичних джерел; (2) систематизація даних теоретичного аналізу та їх узагальнення.

\section{Результати \\ Results}

Розвинена рефлексія передбачає процеси усвідомлення, навмисності, довільності, однак, за свідченням О.Леонтьєва, вона може відбуватися і спонтанно, на початкових рівнях усвідомлення - «неусвідомленості», «несвідомого контролю». (Леонтьев, 1999). І саме такі характеристики властиві процесу засвоєння дитиною мови, адже цей психоментальний процес відбувається в неї на неусвідомленому, мимовільному, ненавмисному рівні (Калмикова \& Новікова, 2018). Вчені дають таке потрактування того як відбуваються ці процеси: неусвідомленість - дитина, засвоюючи рідну мову, не об'єктивує пї як систему одиниць, знаків, кодів; мимовільність - в дитини відсутня мета засвоєння мови, як і усвідомлений вибір: оволодівати чи ні мовними знаннями. Дитина не прикладає вольових зусиль в напрямку опанування знань мови, до цього іiі спонукають ситуації мовленнєвого спілкування, пізнавання, навколишнє середовище, гра, іграшки, картинки, привабливі 
речі. Ненавмисність - дитина спеціально не виявляє орієнтувальну активність, в процесі якої вона приймає рішення про оволодіння мовою. Означені особливості, на думку вчених, підкреслюють натуральний, латентний, наочно невловимий, зовні непомітний для іншої людини процес імпліцитного освоєння знань мови, дія якого відчувається й опосередковано проявляється тільки в мовленнєвій комунікації. Отже, для природного освоєння мови характерне здійснене ненароком, без мети й наміру, ненавмисне, ніби мимохіть, спонтанне й випадкове оволодіння, зумовлене тією чи іншою ситуацією мовленнєвого спілкування (Калмикова \& Новікова, 2018). Однак, успішний процес засвоєння дитиною мови неможливий без паралельного розвитку метамовної функції, завдяки якій відбувається розмежовування засвоєного (Якобсон, 1996).

Форми прояву у дошкільників рефлексії над мовою і мовленням в ситуаціях природного спілкування описано в роботах М. Єлісєєвої, Л. Калмикової, Є. Кларка, Г. Новікової, Р. Шмідта.

М. Слісєєва описує такі прояви дитиною мовної рефлексії в мовленні в природному середовищі. За спостереженнями вченої, перші випадки прояву мовної рефлексії реєструються орієнтовно в 2 роки і мають вияв самовиправлення. Надалі мовна рефлексія виявляється у висловлюваннях, які демонструють контроль над власним мовленням, виправлення мовлення співрозмовників (дітей і дорослих), мовні оцінки власного мовлення і мовлення оточуючих, випадки дитячої етимології, питання метамовного характеру, питання про значення слів. Авторка виділяє такі типи дитячих самовиправлень: прямі самовиправлення без впливу ззовні; непрямі самовиправлення, ініційовані непрямими виправленнями дорослих; непрямі самовиправлення, ініційовані прямими виправленнями дорослих. Дослідження показало, що прямі самовиправлення з'являються в 2 роки і їх кількість постійно зростає, але після 4-х років їх стає менше. Дослідниця робить висновок про те, що мовленнєві самовиправлення є критерієм переходу дитини до нового етапу засвоєння того чи іншого мовного явища. Вчена також зазначає, що мовна рефлексія властива тією чи іншою мірою всім дітям, адже без певних іiі проявів засвоєння мови практично неможливо (Елисеева, 2015).

Прояви мовної рефлексії дитини, які описано у дитячій літературі, аналізує Т. Воробйова. Дослідниця наводить такі їі форми, як: лексико-семантичний протест, виправлення, розмірковування про мову, розмірковування про графіку, словотворчі інновації, і підкреслює, що автори творів для дітей наводять приклади мовної рефлексії, які можна спостерігати в процесі мовленнєвого онтогенезу. Цінним $є$ висновок Т. Воробйової про те, що читання дітям (або дітьми) творів, в яких описано прояви мовної рефлексії є важливим для мовленнєвого розвитку дитини (Воробьева, 2019). 
I. Овчиннікова, розглядаючи питання розвитку метамовної здібності, аналізує погляди зарубіжних психолінгвістів. Так, за даними Е. Кларк, дошкільники оцінюють більшою мірою правила мовленнєвої поведінки, доцільність висловлювання, вони більшою мірою орієнтовані на комунікативну взаємодію, ніж на оцінювання правильності мовлення (Clark, 1978). Р. Шмідт пропонує розрізняти усвідомленість, яка стосується мотивації мовця: так дитина зазвичай добре розуміє до кого з дорослих треба звернутися, щоб не отримати відмову. Свідомий підхід, на його думку, полягає у дотриманні правил і доборі мовних засобів для втілення власної інтенції (Schmidt,1993). Отже, рефлексія як компонент метамовної компетенції пов'язана з усвідомленням комунікативного наміру і свідомим вибором засобів (Овчинникова, 2004).

За даними досліджень Л. Калмикової, мовна рефлексія виникає у дитини в три роки, ii прояви зумовлені бурхливим оволодінням засобами мови; вона має ситуативний і спонтанний характер. Вчена описує такі зовнішні прояви мимовільних спостережень дошкільників 4-5 років над власними висловлюваннями i висловлюваннями однолітків: судження про елементи мови і мовлення, спонтанні оцінно-контрольні дії, виправлення помилок однолітків, внесення коректив в своє мовлення в процесі висловлювання, спрощення лексико-граматичних засобів у спілкування з молодшими дітьми, й робить висновок, що ці процеси відбуваються на рівні несвідомого контролю та ненавмисного, мимовільного, несвідомого та ситуативного регулювання своєї мови (Kalmykova, Kharchenko \& Mysan, 2021).

\section{Висновки Conclusions}

Коло досліджень, присвячених проблемі розвитку рефлексивних мовленнєвих процесів у дітей дошкільного віку поступово розширюється. Зібрані емпіричні дані дають змогу вченим визначити віковий період, а це - 2-3 роки, в якому дитина починає виявляти рефлексивне ставлення до мовних засобів, які вона засвоює i використовує в ситуаціях природного мовленнєвого спілкування 3 дорослим, а згодом - і до свого мовлення в ситуаціях взаємодії з дорослими і однолітками.

Рефлексія виникає у дитини як необхідна складова природного процесу засвоєння мови і розвитку мовлення. Прояви рефлексії у дошкільників в ситуаціях природного мовленнєвого спілкування сприяють контролю i регуляції їхнього мовлення, однак вони також спонтанні і ситуативні за своєю природою. 


\section{Література References}

Выготский, Л.С. (1984). Собрание сочинений. (Т.4). Москва: Педагогика.

Воробьева, Т.А. (2019). Языковая рефлексия ребенка в отечественной и зарубежной детской литературе. https://cyberleninka.ru/article/n/yazykovaya-refleksiya-rebyonka-votechestvennoy-i-zarubezhnoy-detskoy-literature/viewer

Елисеева, М.Б. (2015). Прямые и косвенные самоисправления в речи детей дошкольного возраста. https://cyberleninka.ru/article/n/pryamye-i-kosvennye-samoispravleniya-v-rechidetey-doshkolnogo-vozrasta/viewer

Калмикова, Л., \& Новікова, Г. (2018). Психолінгвістичні феномени «знання мови» і «знання про мову»: проблеми співвідношення й функціонування в мовленні дітей. Psycholinguistics, 23(1), 99-118.

Леонтьев, А.А. (1999). Основы психолингвистики. Retrieved from https://psy.wikireading.ru/h9jREhLmZt

Овчинникова, И. (2004).Что такое метаязыковая способность. Интернет-журнал Филолог, 7. Retrieved from http://philolog.pspu.ru/module

Цукерман, Г.А. (1989). Условия развития рефлексии у шестилеток. Вопросы психологии, 2, $39-46$.

Якобсон, Р.О. (1996). К языковедческой проблематике сознания и бессознательности. Язык и бессознательное. Москва.

Kalmykova, L., Kharchenko, N., \& Mysan, I. (2021). Reflection in the child's speech development. $12^{\text {th }}$ ISAPL International Online Congress, Livro de resumos. Abstract book.

Clark, E. (1978). Awareness of language: Some evidence from what children say and do. In: A. Sinclair, R.J. Jarvella \& W.J.M. Levelt (Eds.), The Child's Conception of Language. (pp. 105-123). New York: Springer-Verlag; Berlin: Heidelberg. https://doi.org/10.1007/978-3642-67155-5_2

Schmidt, R. (1993). Consciousness, learning and interlanguage pragmatics. In G. Kasper, \& S. BlumKulka (Eds.), Interlanguage pragmatics (pp. 21-42). Oxford: Oxford University Press. 